\title{
Plastics: are they part of the zero-waste agenda or the toxic-waste agenda?
}

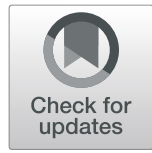

Atiq Zaman *i] and Peter Newman

\begin{abstract}
Background: Plastics were considered as a magical material owing to their strong, non-degradable and versatile characteristics. After five decades of mass application, plastics' property of non-biodegradability has become one of the key concerns for scientists, civil society and government owing to the pollution and damage that plastics cause to our environment. Globally we have generated 8.3bn tonnes of plastics since 1950s and around 9\% has been recycled, $12 \%$ incinerated and the remaining $79 \%$ of the plastics has ended up in the environment. The core question is, should this waste be minimised through the zero-waste agenda or banned through the toxic-waste agenda?

Results: The study analyses the zero plastic waste agenda and the toxic plastic waste agenda. It analyses zerowaste practices at different levels including family to community, industry and city levels. In addition, the study investigates the need to phase out toxic plastics. The study identified the need for both approaches. As plastics promote the throwaway living which is responsible for generating undesirable waste, it should be tackled through better design principles and sustainable consumption practices for the short-term agenda. The study proposes a strategic zero plastic waste framework for moving towards a zero plastic waste society. At the same time, there is a need to identify those plastics that are leading to serious and toxic impacts through micro-particles that necessitate them to be phased out more quickly through transitioning to bio-plastics.

Conclusions: Both zero plastic and zero toxic agendas are urgently needed. The study concludes that at least three things in the short term need to be implemented simultaneously to achieve a zero plastic waste society. Firstly, through zero-waste design - to eliminate creating any unnecessary plastic waste through closed-loop design thinking. Secondly, through responsible and collaborative consumption - to avoid and reduce generating avoidable plastic waste. Finally, through zero-waste management - to prioritise the value, retain the wasted materials and recover all resources. The study also establishes that a new long-term agenda needs to be created to identify those plastics that must be phased out owing to their toxicity. Consequently, the study suggests a process to achieve it in line with the transition to the post fossil-fuel era through United Nations initiatives as a joint action of the Paris Agreement and the Basel Convention.
\end{abstract}

\footnotetext{
*Correspondence: atiq.zaman@curtin.edu.au

Curtin University Sustainability Policy Institute, School of Design and the Built

Environment|, Curtin University, Bentley, Perth, Australia
}

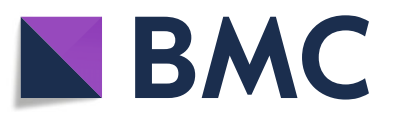

(c) The Author(s). 2021 Open Access This article is licensed under a Creative Commons Attribution 4.0 International License, which permits use, sharing, adaptation, distribution and reproduction in any medium or format, as long as you give

appropriate credit to the original author(s) and the source, provide a link to the Creative Commons licence, and indicate if changes were made. The images or other third party material in this article are included in the article's Creative Commons licence, unless indicated otherwise in a credit line to the material. If material is not included in the article's Creative Commons licence and your intended use is not permitted by statutory regulation or exceeds the permitted use, you will need to obtain permission directly from the copyright holder. To view a copy of this licence, visit http://creativecommons.org/licenses/by/4.0/. 


\section{Introduction}

"We made plastic, we depend on it, now we're drowning in it” [57]. In her article, 'Planet or Plastics', Parker outlined an inconvenient truth of plastic problems and how our oceans are being filled with non-biodegradable plastics over time. Plastics are synthetic and semi-synthetic polymers which form long-chain molecules made of repeating links or monomers. The vast majority (92\%) of plastics are thermoplastics, meaning they are characterised by being meltable and the rest are thermoset plastic, meaning they are characterised by not being meltable [2]. According to ACC [2], the chemical properties and physical characteristics of plastics vary depending on their combinations of monomers e.g. homopolymer (same monomer) or co-polymer (more than one monomer). The versatile characteristics of plastics make the material so impressively useful that they can be found in almost every single product that we buy today. Apart from a very small proportion, less than $1 \%$ of plastics are produced from biobased natural sources [28]. The remaining 99\% of plastics are derived from oil and are created using a range of chemicals including chlorine and phosphorus that are known to cause complications in the natural environment for many decades $[18,75]$.

Because of their sturdiness and low-degradability, the very characteristics of oil-based plastics [71], e.g. mass application of plastics, have now become the biggest concern of many individuals, scientists, communities, industries and governments owing to its poor management. Waste plastics are causing significant pollution to the environment [6], especially in their microparticle form as they enter into food chains [23] in a way not seen since the days when chlorinated hydrocarbon pesticides began the environmental revolution in 1960s, soon after the publication of 'Silent Spring' [18]. Microplastics appear to be an inevitable breakdown product of all plastic but are also more easily derived from some plastics [21]. There is also research now showing that plastic nanoparticles are a further breakdown product with potential to cross membranes and cause serious biological damage [17].

According to Geyer, Jambeck et al. [32], globally we have generated $8.3 \mathrm{bn}$ tonnes of plastics since 1950s and only $9 \%$ has been recycled, $12 \%$ incinerated and the remaining $(79 \%)$ has ended up in the environment (Fig. 1). It means that the traditional waste management system has failed to ensure a safe and sustainable management of plastic waste. The study also predicted that if current production and waste management trends continue, roughly $12 \mathrm{bn}$ tonnes of plastics waste would end up in landfills or the natural environment by 2050 [32].

Unmanaged or poorly managed plastic wastes (at least the oil-based plastics dominating the market now) are a great threat to our planet. The Basel Convention's recent amendment in 2019 lists plastics as toxic wastes. The conversion restricts the transboundary movement of plastics [8]. Therefore, further research and critical analysis are required to understand how plastics are now part of the toxic waste agenda.

The term 'agenda' is used in public policy as what government officials find important to discuss [86]. The importance of plastics waste is the topic of this paper as it can be seen differently if just a short-term agenda rather than the way it is increasingly being seen as having a long-term problem. Thus the agenda is set as either a short term problem of reducing plastic waste or a long term problem of toxic plastic waste. According to Rogers and Dearing [67], an agenda-setting model is comprised of three components: media agenda, public agenda, and policy agenda. The priority areas under the agendas can be

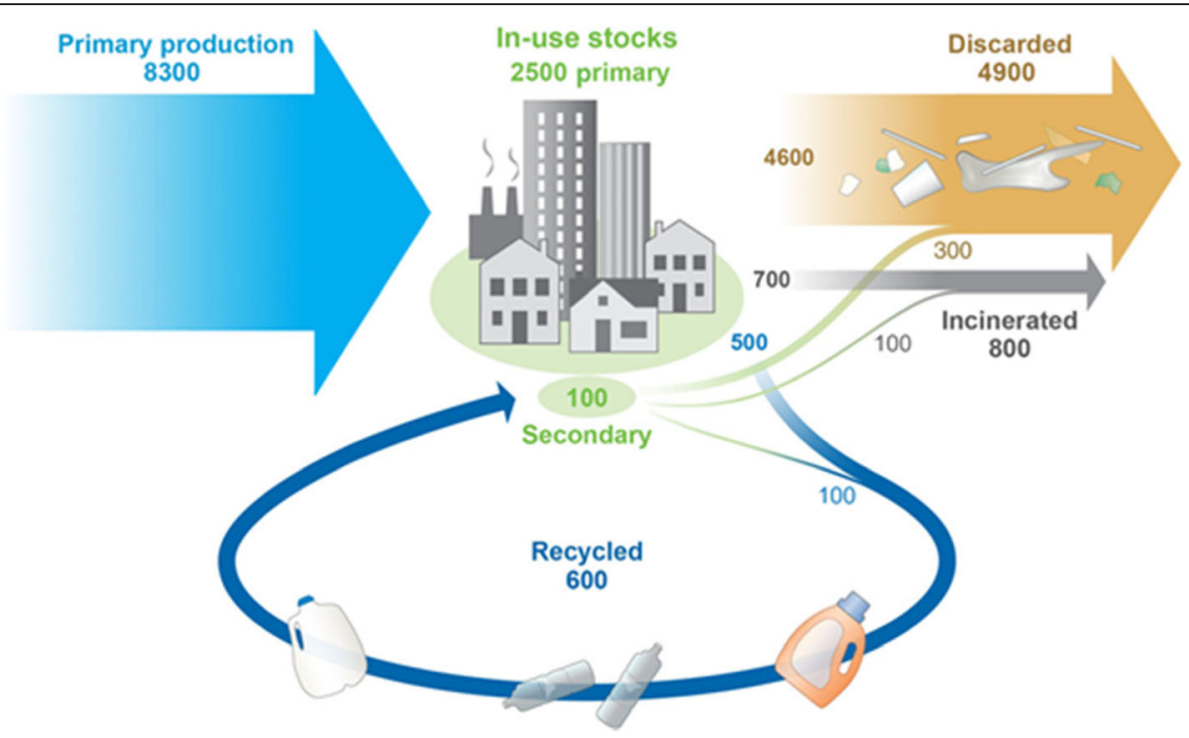

Fig. 1 Global plastic production between 1950 and 2015 (in million metric tons). Source, with permission Geyer, Jambeck et al. [32] 
identified and determined on the basis of public opinion with the consideration of perception, potency (adverse impact), power and proximity. In the current social media era, the agenda is often influenced and developed through personal experiences and interpersonal communications from individuals, organisations, media, public and policy discourses [5].

This empirical study questions whether the new awareness of plastic's damage necessitates a paradigm shift from the 'traditional' plastic waste management system where plastic is simply a growing part of the 'zero-waste' management agenda or whether it has moved into the new 'toxic waste' agenda. This study explores core elements of agenda setting by analysing the perceptions of zero plastic waste and zero toxic waste and by revisiting the adverse impacts of current waste problems. In addition, the study provides policy recommendations by dissecting the influential power/role of various stakeholders (governments, community, industry) and their proximity to the zero plastic waste and zero toxic plastic waste agenda.

Zaman [89] proposed a strategic framework for working towards zero-waste societies. Given the current challenges of plastics waste, this article examines the barriers and possible opportunity to move towards a zero-plastic waste (ZPW) society and eventually phasing out of plastics in the post-fossil fuel era. The zero-waste concept is seen as a visionary approach for moving forwards from current unsustainable waste management practices [91]. Many communities, organisations and cities have already considered zero-waste as part of their sustainability agenda [89]. This article begins by examining plastic waste in this zero waste agenda and we argue that a zero plastic society is moving towards being considered a necessity, however, it is an ambitious target. We then argue that plastic should increasingly be seen as part of the toxic waste agenda or as the EU labels it the 'non-toxic environment' agenda [29]. The non-toxic environment agenda is where substances like PFAS are removed, and this paper questions whether the non-toxic environment should now include plastics.

Thus, the primary objectives of this study are to:

- analyse the key challenges of plastics waste management based on a review of grey and scholarly literature;

- examine the concept of zero-waste and how it would address the challenges through the analysis of current zero-waste practices;

- examine the reasons for considering plastic wastes as toxic and how to move towards a non-toxic environment; and

- provide a set of strategic recommendations for implementing both short-term zero plastic waste and long-term zero-toxic waste agendas.

Section 2 provides the background to the zero-waste and toxic waste agendas in relation to plastics. The qualitative research methods are outlined in Section 3, followed by Section 4 which examines the key challenges of both the zero-waste and zero-toxic agendas through the lens of cross-case analysis of current practices. Section 5 outlines the possible way forward to achieving the zero-waste and zero-toxic waste goals for plastic.

\section{Theoretical background}

The theoretical framework of this study is grounded on the concept of zero-waste and broader circular economy principles, outlined below. This study endeavours to investigate whether zero-waste as an agenda is appropriate and how the zero-waste principles can be applied to address global plastics' problems. The study also analyses whether the extension of the zero waste agenda to the toxic waste agenda is needed in order to conclude how far plastic as a problematic impactful material, falls into each agenda.

The study concludes by envisioning how in the short and long term plastics should be treated as part of both agendas. For example, zero waste deals with material recovery and material circulation within the society. Many councils and local governments are developing new roads using plastics waste and this may meet the principles of the zero-waste agenda in the context of waste diversion from landfill and the material circularity within society. However, certainly the practice would not meet the principles of the zero toxic agenda, because as detailed below plastics are soon broken down to micro and nanoplastics due to traffic and weathering processes once they are used in the road base. As a result, the toxicity of the micro and nano plastics will continue to deplete the environment beyond the short term zero waste agenda.

Although the term 'zero-waste' was coined in the 1970s, the concept is still in development and the zerowaste principles are evolving over time [87]. The implementation of the zero-waste principles is still limited in community, organization and urban scales. The zerotoxic or non-toxic agenda is more universal and the agenda has already attracted global attention. Development of a non-toxic environment strategy by 2018 is already part of the 7th Environment Action Programme of the European Parliament and the Council [29]. In this article the term principles is used as one of the priority areas under the agenda setting. The findings and recommendations of the study would benefit policymakers to understand the broader plastics problems and potential solutions through both the zero-waste and toxic waste agendas.

\section{The principles of zero-waste}

Waste is commonly assumed to be a valueless and unavoidable by-product that is created at the end of a product's life phase. The zero-waste approach directly challenges this common assumption and finds the ways 
to reuse the so-called "waste" by-products. The toxic waste approach states that merely minimising plastic waste impacts is not enough. Rather, in this approach all plastic waste is a poison that cannot be tolerated. So, the question becomes whether we are moving towards seeing plastic waste as being akin to something like highlevel radioactive waste, i.e. a dangerous pollutant that must be prevented from entering the environment?

Zero-waste acknowledges that waste is a 'misallocated resource' or a 'resource in transition' which is produced during the intermediate phases of production and consumption activities. Thus, it should be recirculated to the system to reuse, reassemble, resell, redesign, recycle or reprocess [88]. Zero-waste does not see 'waste' as a substance that must be disposed of or incinerated, rather it considers waste as a resource that should be used again [33]. One of the core principles of the 'zero-waste' concept is to conserve and retain the resource's value. The traditional waste management system often destroys the product and its resource value since the main emphasis is given to safe disposal of the waste. The 'zerowaste management' system retains the product and resource value by considering the top of the waste hierarchy e.g. reduce, reuse, repair, resell and recycle. One of the questions in this paper is whether a substance like plastic can be reused effectively and safely when its micro-particle degradation products are now being perceived as a very dangerous product. Thus, can plastic be managed as part of the zero-waste agenda or is it part of a toxic-waste agenda?

Generally, value is added in various phases of a product's life cycle such as extraction of resources, refinement of raw materials and manufacturing of new products until retail of the products. Rather than retaining the value of the post-use products, the traditional waste management system destroys the value and hardly retains it at the lowest level through traditional resource recovery and recycling. In the zero-waste approach, the priority is given to retain the value as much as possible at the 'downhill' phase (value recovery of post-use phase) as shown in Fig. 2 using the circular economy model [3].
Zero-waste considers circular design principles for reuse and recycle. Therefore, the fundamental difference between the traditional waste management and the zerowaste management approach is that waste is considered as a resource in transition which needs recirculation within the system.

Table 1 shows the key difference between traditional waste management and the zero-waste management approaches [91].

\section{Plastics in the zero-toxic waste agenda}

In their recent publication "Designing for a green chemistry future", Zimmerman, Anastas et al. [93] stated that "a sustainable society will depend on chemical products and processes that are designed following principles that make them conducive to life." The characteristics of products need to be considered at the beginning of any design stage by addressing the issues of depleting versus renewable, toxic versus benign and persistent versus readily degradable [93]. A toxic or hazardous waste is a waste with properties that make it dangerous or capable of having a harmful effect on human health or the environment [72].

Plastic waste releases toxic constituents such as Dioxins, Furans, Mercury and Polychlorinated Biphenyls into the natural environment during incineration and degradation (microplastics) [82]. Various studies have confirmed that plastic breaks into smaller pieces that propagate through food chains and the ingested microplastics can cause harm $[16,58,66]$. The recent studies have revealed that polystyrene is harmful for the central nervous system $[82,83]$. Owing to the shortfall in the global regulatory frameworks such as the Stockholm and Basel Convention, there were no restrictions on the transboundary movement of plastics waste from one country to another [63].

With the recent awareness of the global threat to environmental pollution from plastic and its breakdown products, plastic waste was listed under the Basel Convention in 2019. The recent amendment of the Basel Convention forbids the trade between parties and non-

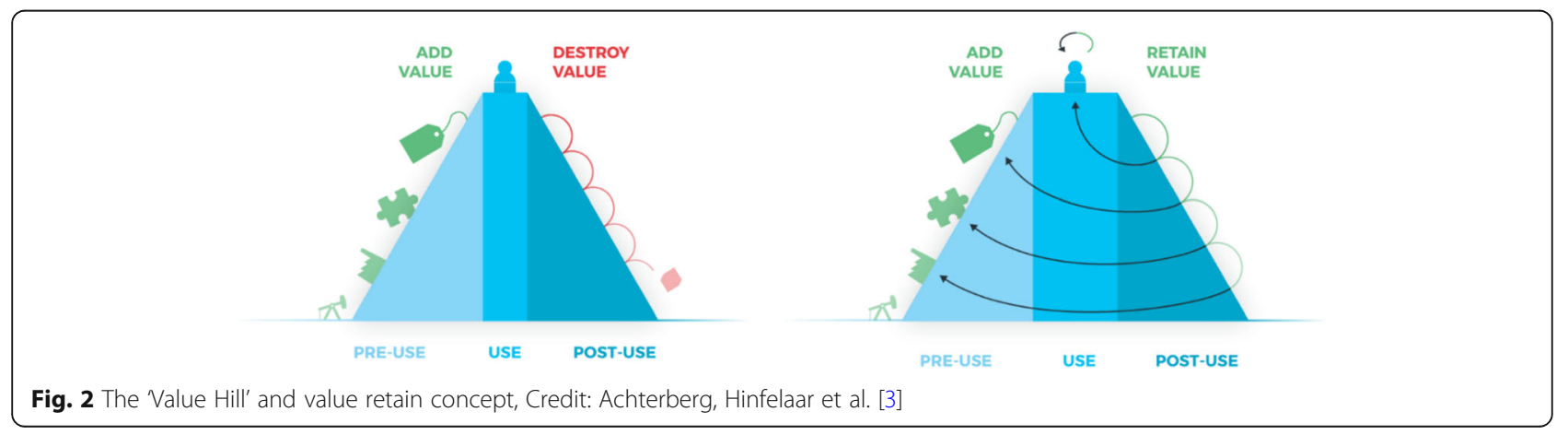


Table 1 The difference between traditional waste management and zero-waste management ([91])

\begin{tabular}{ll}
\hline Traditional Waste Management & Zero-Waste Management \\
\hline Waste is considered as the end of the resource life cycle & $\begin{array}{l}\text { Waste is considered as resource in transition or an intermediate phase of a } \\
\text { resource life cycle. }\end{array}$ \\
$\begin{array}{ll}\text { Perceives waste as mainly a technological problem and thus often } \\
\text { relies on engineering solutions (e.g. landfill, incineration) }\end{array}$ & $\begin{array}{l}\text { Perceives waste as both social and technological problem and thus seeks } \\
\text { social technology (e.g. reuse/recycling) as well as engineering (e.g. anaerobic } \\
\text { digestion) solutions } \\
\text { Highly depends on landfill and incineration technologies }\end{array}$ \\
$\begin{array}{ll}\text { Highly depends on waste avoidance and prohibits landfill and incineration } \\
\text { technologies. }\end{array}$ \\
$\begin{array}{ll}\text { Conservation of resources instead of depletion, e.g. reuse and recycle instead } \\
\text { wimited job opportunities }\end{array}$ & $\begin{array}{l}\text { of waste-to-energy } \\
\text { Comparatively a higher number of job opportunities }\end{array}$
\end{tabular}

parties of exporting plastics aiming to eliminate the discharge of plastic waste and microplastics into the environment, in particular the marine environment [8]. The key objectives of the amendments are to enhance the control of the transboundary movements of plastic waste and to clarify the scope of the Convention as it applies to such waste. Translating the initiative into waste policy and environmental management does however seem to be lagging behind.

\section{Research methods}

The aim of the study is to examine the present global plastic waste crisis through the lens of zero-waste and non-toxic principles. The zero-waste concept is a subset of the circular economy paradigm, which aims to regenerate natural systems, design out waste and pollution and keep products and materials in use [26]. The study has applied a qualitative research method to analyse the existing body of knowledge around plastic waste from both grey and academic literature. In addition, the study analyses the zero-waste practices from individuals, business and cities to unlock the potentials of implementing the concept in solving the plastics waste problem. Section 4 analyses the key changes of plastics waste in relation to zero-waste and zero-toxic targets. Section 5 provides the short-term strategies for implementing the zero-waste concept based on the analysis of current practices as well as the long-term strategy for implementing the toxic waste concept. Some overall conclusions are then drawn in Section 6.

\section{Challenges with plastics waste}

\section{Challenges with the zero-waste agenda}

\section{Plastics and throw-away living}

The following sections provide a brief background of plastics in the context of promoting a throwaway society, current management trends and the impending threats to the environment, including the scientific basis for how plastics should be regarded as toxic waste.

Various synthetic plastics that we see around us today were not around in the early twentieth century. Soon after the discovery of synthetic plastic Bakelite in 1907, a variety of plastics such as polyvinyl chloride (PVC), polyethylene (PE), nylon, polystyrene (PS), polypropylene (PP), polyethylene terephthalate (PET), High-density polyethylene (HDPE), were introduced over the next five decades [37]. Plastics appeared as a 'magical' material owing to their extraordinary properties. Victor Yarsley \& Edward Couzens [84], in 'Plastics', wrote "Let us try to imagine a dweller in the 'Plastic Age' .... a world in which man, like a magician, makes what he wants for almost every need" (p3). Plastics started being used in different purposes and they replaced numerous conventional materials such as metals in car parts to ivory in buttonhooks or combs [30]. During World War II, plastic production in the United States increased by $300 \%$ due to use in aircraft windows and plastics combs for all soldiers [55].

Plastics were used as an enabler for reviving the global economy from the Great Depression with the aim of 'planned obsolescence', i.e. producing low-cost, single used products. Plastics aptly serve this purpose of shortlasting and single used products. Thus, the mass application of plastics in consumer products started once the new modern economy post-depression and post the Second World War began with the goal of creating jobs and increasing economic growth. The technological innovation (especially in polymer technology) made it possible to offer cheaper and better products to consumers. At one time, the concept of throwaway living was only reasonable for wealthy people, but now, owing to the availability of plastic products, throwaway living became affordable for all including the poorest in all societies. The 'throwaway living' concept was promoted in a featured article in 1955 by LIFE Magazine (Fig. 3) because one did not need to worry about cleaning plates or dishes and household plastic products were so inexpensive due to industrial mass production that everyone could now afford a throwaway lifestyle [20].

Global production of resins and fibres increased from $2 \mathrm{Mt}$ in 1950 to $380 \mathrm{Mt}$ in 2015 with an annual growth rate of $8.4 \%$, whereas the global gross domestic product 


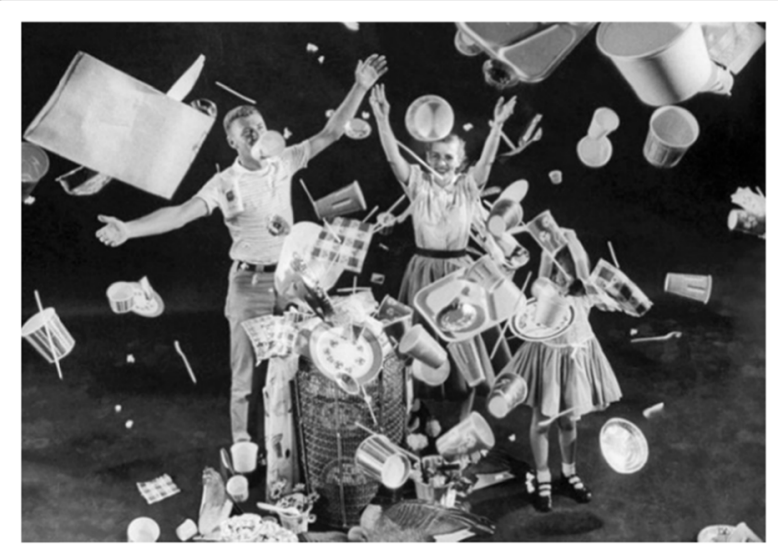

Fig. 3 The 'throwaway living' concept was advertised in 1950s by LIFE Magazine [20]

(GDP) increased roughly $2.5 \%$ per year during that period $[32,60]$. Plastics have been used predominately in packaging (36\%) followed by building and construction (16\%) and textiles industries (15\%). The average usage time of plastics in different purposes varies before they are discarded and become wastes. Figure 4 shows the use of plastics and their lifespan by industries. It is apparent that a significant proportion of packaging plastics (161 million tonnes) that we generate today is discarded after less than just 6 months [57].

The challenges of global plastics waste management due to China waste ban

Until 2017, China had been taking in up to $56 \%$ of the world's plastic garbage to recycle with a significant proportion of contamination (paper and other undesirable materials) [69]. In January 2018, China enacted its "National Sword" Policy. It banned the import of 32 different types of solid waste with a threshold of over $0.5 \%$ contamination level, including plastics and papers which impacted nearly half of the world's recyclable waste. China's decision to no longer be the dumping ground for the world's recycled waste which they had been doing for the previous quarter century left municipalities and waste companies around the world scrambling for alternatives [42]. Prior to China's ban, 95\% of the plastics collected for recycling in the European Union, $70 \%$ in the U.S. and $12 \%$ in Australia used to be sold and shipped to Chinese processors [12, 42].

In response to China's waste ban, the Australian governments (states and territories responsible for waste management but co-ordinated by the Federal Government) have revised their waste policies and set targets for improving or creating a local waste industry. One target is the $100 \%$ recyclable packaging target which means that all Australian packaging be recyclable, compostable or reusable by 2025 . However, a $100 \%$ target is an important vision, but it does not mean that all the waste in Australia generated in 2025 will necessarily find its way to one of these destinations [90]. This will depend on the management systems that can be put in place in a timely manner. Plastics are a case in point.

The recycling of plastic bottles (PET) is considered one of the most cost-effective waste methods as there are established policies such as container deposit schemes or similar schemes in different countries that are highly successful, however, the numbers are not globally encouraging. According to Euromonitor, around 480 bn plastic bottles were sold globally in 2016 and less

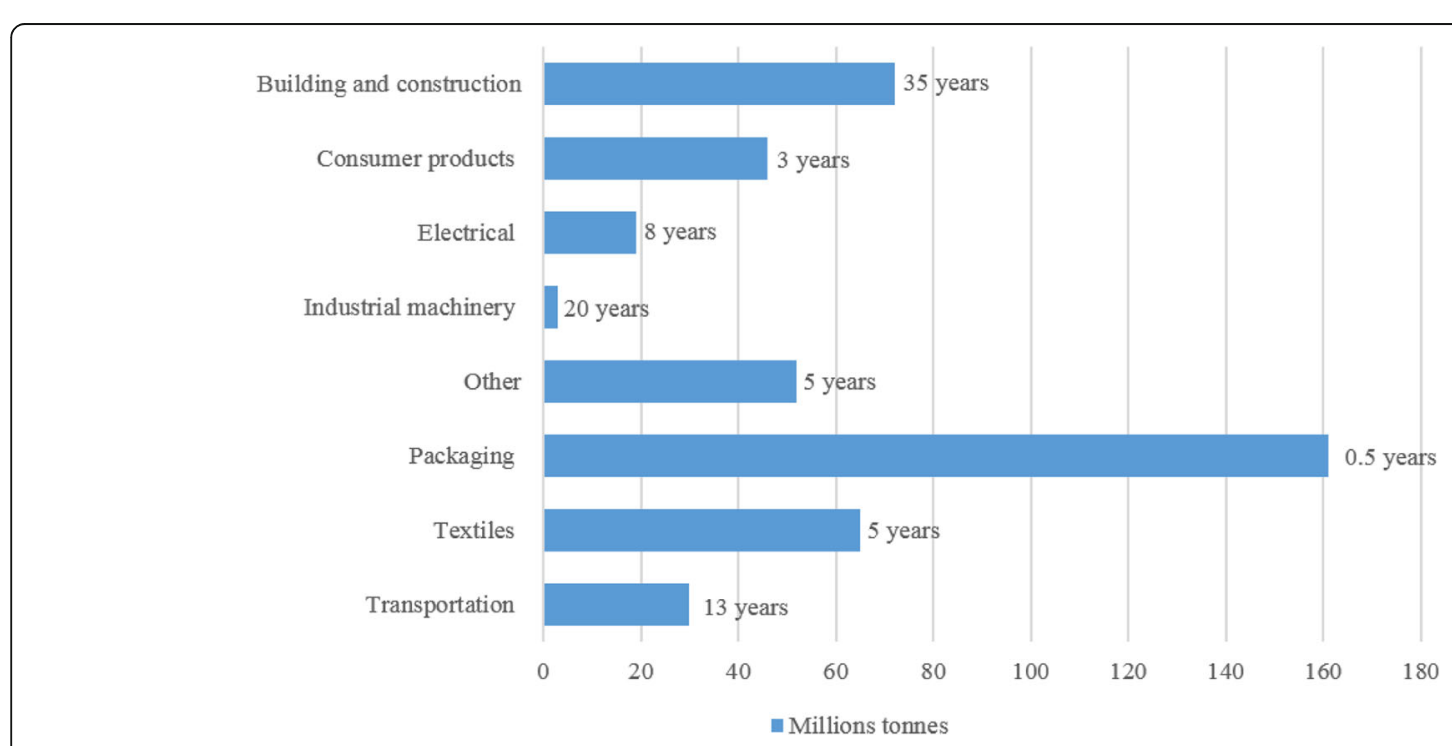

Fig. 4 The Use of plastics and their lifespan by industries (adapted from [32]) 
than $50 \%$ of the bottles were recycled and only $7 \%$ were used to make new bottles [9]. There are various reasons behind current poor recycling practices around the world. The key reasons are briefly described in the following sections.

\section{Design issues leading to generate more unwanted waste}

Plastic packaging does have many benefits when it comes to preserving foods and goods. However, the design flaws of packaging, especially unnecessary plastic packaging results in generation of problematic waste that is difficult to recycle as it was designed for single use. In the name of shoppers' or retailers' conveniences for bulk selling, unnecessary packaging has now become common in almost all grocery shops around the world. It is now seen as 'unnecessary' for consumers to have such packaging but it has become part of the cultural and economic fabric of much retailing. Figure 5 shows examples of unnecessary packaging of fruit and vegetables. Depending on local recycling infrastructure, this packaging often ends up in landfill. Therefore, innovative design and retail management by eliminating unnecessary packaging as well as responsible consumption practice in relation to buying package-free products are the primary waste avoidance strategies to address waste challenges, consequently moving towards zero-waste.

\section{Confusion around right recycling due to various plastic codes}

Based on recycling codes, plastics are broadly categorised into seven types such as type 1- polyethylene terephthalate (PETE/PET), type 2- high density polyethylene (HDPE), type 3- polyvinyl chloride (PVC), type 4- low density polyethylene (LDPE), type 5popypropyline (PP), type 6- polystyrene (PS) and type 7all others. Figure 6 shows the level of difficulties in recycling different types of plastics. Among various types of plastics, PET and HDPE are considered to be easily recycled, LDPE and PP are manageable, PS is difficult to manage and PVC and other types of plastics are very difficult to recycle [57].
A variety of technologies and infrastructure capacities are required to manage all plastics types locally. As a result, plastics recycling infrastructure varies at different locations, thus local residents need to be aware of the local infrastructure capacity and acceptable recyclable plastics types. Often it creates confusion around correct recycling types as it is very difficult for people to remember which plastics are acceptable in their local area. New technologies for branding types of plastics so that consumers can easily use a mobile phone to scan the product and know its local recyclability would seem to be an obvious market response to this issue.

\section{Technological limitations and costs of recycling}

Recycling of all types of plastics requires a combination of several advanced technologies and the technology often comes with a huge price tag. Consequently, waste recycling technologies mainly cover the activities of sorting and recycling of selected waste categories such as PET, HDPE, some LDPE and PP, which are considerably easier and low cost to recycle. Without very sophisticated and advanced sorting technology, a certain level of contamination can be found. Several reports indicated that design flaws mainly in the product packaging, incorrect recycling behaviour and the lack of sophisticated waste sorting technologies are the key reasons behind a higher level of contamination in Australia [19, 65, 70].

Waste markets are another big influential driver to effectively prevent recycling of plastics. In Victoria, Australia, kerbside collection cost of recyclables in 2016 was AU \$115 for each tonne [7]. The market value of recovered mixed-plastics of each tonne of kerbside waste recycling was only AU\$ 2 and the market value of all recyclables (including aluminium, glass, plastics, paper and cardboard) was AU $\$ 82$ which is significantly lower than the collection cost. The waste value has significantly declined as a result of China's waste ban. Table 2 shows the value change of the waste commodity market before and after the China waste ban [7].

All the above factors will need to be worked through if a zero-waste agenda for plastics is to be implemented.
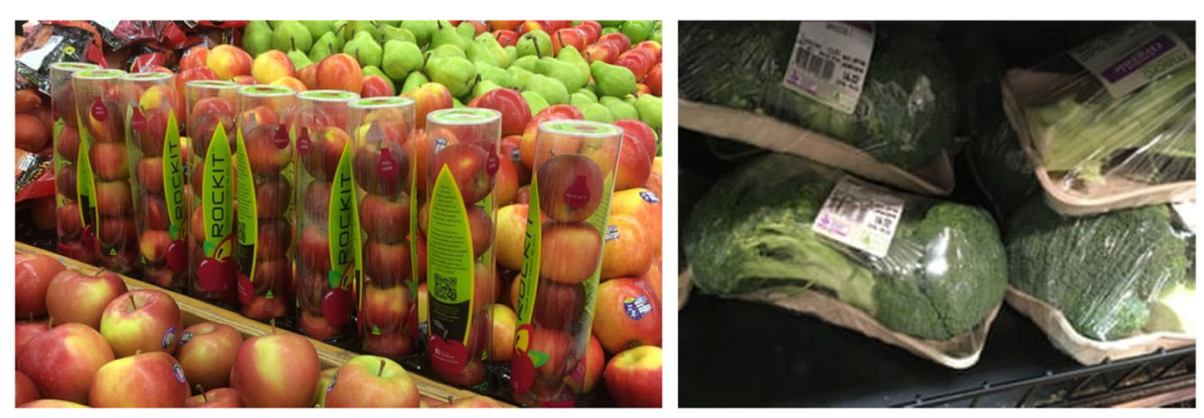

Fig. 5 The examples of an unnecessary packaging [73] 

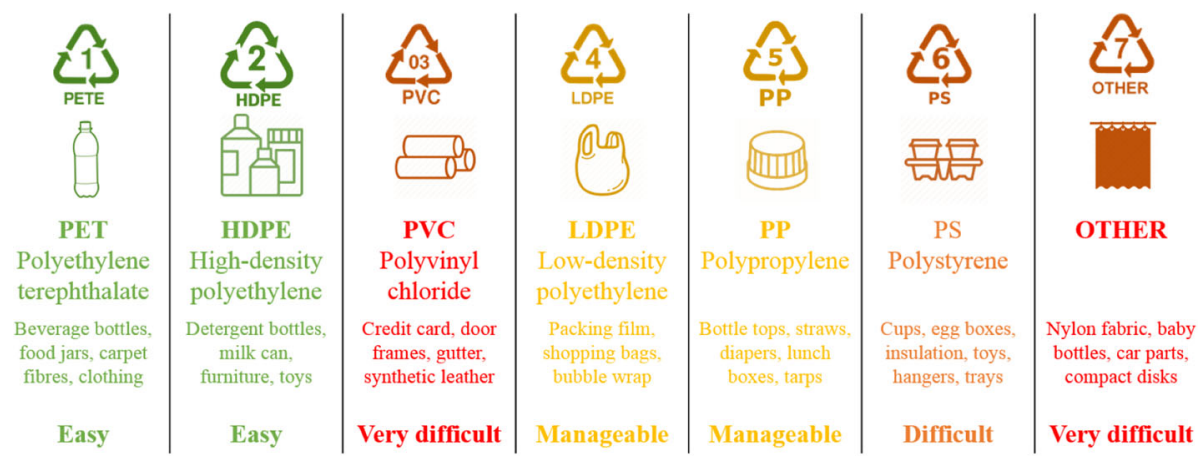

Fig. 6 The level of difficulties of recycling different plastics

\section{Challenges of plastics with the zero-toxic waste agenda}

The environmental pollution of plastics starts at the beginning of manufacturing as the majority of the plastic resins come from petroleum-based fossil fuel sources (mostly oil) and the pollution continues even after the final disposal. It was estimated that the emissions from plastics in 2015 were equivalent to nearly 1.8 billion metric tons of $\mathrm{CO}_{2}$ and the emissions from plastics will reach $17 \%$ of the global carbon budget by 2050 [92]. A study has revealed that plastics waste that is exposed to sunlight and degrades in the environment emits several greenhouse gases including methane and ethylene [68].

Since $79 \%$ of all plastics have ended up in the environment through land or water, these plastics will exist and continue to pollute the environment for hundreds of years as the decomposition rate of plastics is generally very slow. Simple plastic PET bottles, straws or even single used plastics take 450 years, 200 years and 20 years respectively to completely degrade in the environment [45]. The carbon footprint of plastic (LDPE or PET, polyethylene) is about $6 \mathrm{~kg} \mathrm{CO}_{2} \mathrm{e}$ per $\mathrm{kg}$ [78] and about $85 \%$ recycling content in $\mathrm{PET}$ bottles can reduce the carbon footprint by $74 \%\left(1.54 \mathrm{~kg} \mathrm{CO}_{2} \mathrm{e}\right)$ [24].

The discovery of the Great Pacific Garbage Patch (GPGP) illustrates the level of long-term pollution and damage that is occurring in our marine environments. It is estimated that 1.15 to 2.41 million tonnes of plastic are entering the ocean each year from rivers [47], which are responsible for creating five waste gyres (mostly plastics) in the Pacific Ocean also known as the Great Pacific Garbage Patch. The data shows that they are growing rapidly $[44,46]$. The GPGP covers an estimated surface area of 1.6 million square kilometres, an area twice the size of Texas or three times the size of France [46]. The plastics are slowly degrading, creating a slimy mass in the ocean and eventually breaking down to the microplastic level. In the centre of the GPGP, the concentrations reach 100 's of $\mathrm{kg} / \mathrm{km}^{2}$, decreasing to $10 \mathrm{~kg} / \mathrm{km}^{2}$ in the outermost regions [46].

Microplastic mass concentration is increasing exponentially $[46,50]$. It suggests that unless sources of plastic pollution are mitigated and reduced, the number will continue to rise [56]. Studies conducted by Van Houtan, Francke et al. [81] and Young, Vanderlip et al. [85] indicated that there are 180 times more plastics at the surface of the Great Pacific Garbage Patch than biomass and $84 \%$ of plastic samples had at least one chemical pollutant in excess of acceptable limits. This high concentration of plastic pollutants was also found in the stomach of the common North Pacific subtropical gyre surface feeders [77]. Scientists also predict that if nothing changes in our plastic consumption habits, by 2050 there will be more plastic in the oceans than fish (by weight) [25].

Plastic is also finding its way into the marine food web with consequences for humans. Research by the Coastal Ocean Research Institute at Vancouver Aquarium Marine Science Centre [80] discovered that marine zooplankton are ingesting micro-plastic particles, which can be biomagnified through the marine food chain. Quackenbush [62] has also measured plastics in human waste and estimated that "more than $50 \%$ of the world population might have micro-plastics in their stools", which means half of the world population is exposed to have

Table 2 Plastic commodity prices before and after China waste ban

\begin{tabular}{lll}
\hline Items & AU \$/tonne: Pre-China ban (2015-'17) & AU \$/tonne: Post-China ban (2018) \\
\hline Plastic - PET & $\$ 575$ & $\$ 375$ \\
Plastic - HDPE & $\$ 575$ & $\$ 500$ \\
Plastic - mixed & $\$ 325$ & $\$ 75$ \\
\hline
\end{tabular}


health risks that could be attributed to plastics [38]. This is a time bomb that is likely to grow in awareness and clarity as scientific studies are completed on the mechanisms linking microplastics and nanoplastics to human and environmental health.

More scientific studies must be conducted on the toxicology of microplastic particles, but the present data is suggesting that there is a major problem similar to the early studies done on chlorinated hydrocarbon pesticides which were also designed to last forever and to keep working to prevent various pest issues. They too were a magic solution to a real problem but had growing issues as biological systems and human organs were not designed to deal with such chemicals. It seems that plastics are now heading along the same path. This would imply a need to ban them, but as they are so embedded in the economy, it will take a transition strategy. A priority needs to be set by scientific studies to phase out the plastics known to be the most toxic.

Given the present challenges related to plastics waste management and their potential impact on all planetary life, there is a dire need to manage this waste. The Precautionary Principle would suggest that plastics are now moving into a toxic waste category and need to be phased out. The zero-waste emphasis is on the circularity of materials, meaning the resources and materials used in urban metabolism, and the need to be recirculated again and again in a closed-loop system. On the contrary, the non-toxic agenda focuses on the characteristics or toxicity of the materials or resources used in the system, meaning the key focus is not on the circularity of the materials rather the toxicity that pollutes the environment. Given the current waste management challenges, the zero-waste vision can be seen as an inspiring solution and the zero-toxic agenda would be seen as an ultimate solution that we need to consider for a long-term solution. The following sections present how the 'zero-waste' and 'toxic waste' agendas could be implemented in our future to overcome the massive problem we are currently facing.

\section{The way ahead: zero plastic waste and zero toxic waste}

This paper presents both short-term zero-waste and a longer-term zero toxic waste agenda as part of plastics waste solutions. Section 5.1 very briefly presents some zero-waste case study practices from family, community, industry to city levels and stakeholders' involvements and roles in implementing zero waste strategic frameworks. Section 5.2 presents the long term zero toxic agenda.

\section{The short-term zero plastic waste agenda}

There is an influx of interests among individuals, community, industry, government agencies, city authorities, policy makers and many other stakeholders around the zero-waste agenda [91]. It is also evident that some zerowaste practices have been implemented at different levels across household families and communities, industry to city level around the world [11]. The following sections provide examples of these current zero-waste practices and how we can learn from them if we are to adopt Zero waste plastic.

\section{Zero-waste practices in families and communities}

Some households in California [41], Phoenix [51] in USA and Tasmania [1] in Australia and many other places in the world are endeavouring to live without creating any waste. They have shown that it is possible for a modern family to live without creating massive amounts of waste [41]. The necessary supporting infrastructure, for example packaging free bulk grocery shops are very important for the zero waste lifestyle. Figure 7 shows Bulk Market, London's First Zero-Waste Grocery Store (Eco [13]). The store offers both dry products (such as spices, pasta, grains) and liquid items (such as oil, honey, maple syrup).

Kamikatsu, a small community in Japan, has demonstrated how the whole community can achieve zerowaste goals even in the absence of modern waste collection and infrastructure systems. The community doesn't have a traditional weekly collection service and a majority of the population (50.3\%) is over 65 years old. Waste at the recycling centre is sorted into 45 different categories [76]. Each of the main waste types has subcategories, for example cans are subcategorised as aluminium, steel and spraying cans, glass bottles are subcategorised as clear, brown, other and returnable class bottles which means that a higher level of knowledge and understating of waste sorting and recycling issues are needed for the local community to recycle waste

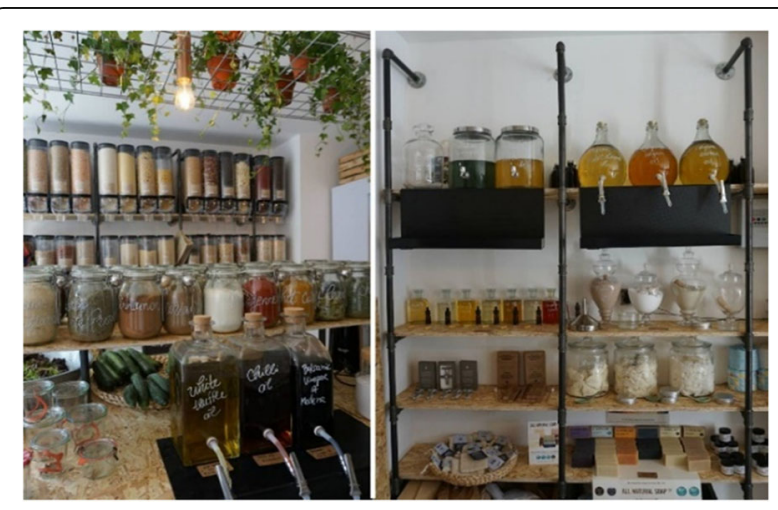

Fig. 7 Zero-waste grocery shop in London (Eco [13]) 
correctly. Figure 8 shows various sorting boxes for different types of waste. Some of the recycling practices can be implemented immediately in towns around the globe, where markets for the recycled products can be established. The developing world has many examples of such local recycling [54].

The zero-waste practices being implemented in Kamikatsu over the past 15 years means that the community is currently recycling around $80 \%$ of the total waste that they generate. The remaining $20 \%$ that can't currently be recycled including nappies and certain types of plastics are sent to landfill [31, 76]. It is evident from the Kamikatsu's case study that despite the aspiration and mass community involvement, the system change in relation to product design is urgently needed to become a true zero-waste community.

\section{Zero-waste practices in industries and cities}

Different consumer brands and companies such as Adidas, H\&M and Fuji Xerox have been implementing zero-waste practices as part of a sustainability initiative. They are usually in partnership with NGOs. Adidas, for example, has been partnering with 'Parley for the Oceans'. Together they retrieve plastic from ocean waste to produce a range of clothing called "Sport Infinity". The Sport Infinity project has the potential to recycle plastic endlessly to make new products through a closed-loop supply chain of sport products [4]. In 2016, around 740 tons of plastic pollution were collected by 'Parley for the Oceans' from the Maldives Indian Ocean, which was turned into yarn and eventually used in Adidas products [59]. Figure 9 shows the yarn and cloth made out of ocean plastics.

San Francisco (California, USA) and Adelaide (South Australia, Australia) have been often referred to as the leading cities around the world when it comes to practicing the zero-waste agenda at a city scale. The cities were ranked first and second best amongst the 22 global

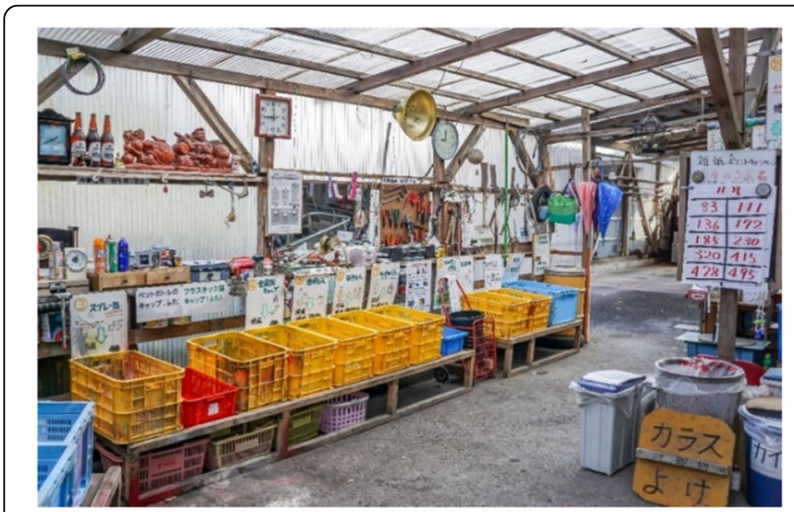

Fig. 8 Sorting options for various resource types at the Kamikatsu Waste Station. (Courtesy: Akira Sakano, Zero-Waste Academy, Japan) cities studies by UN-HABITAT [79]. Both cities have developed and implemented zero-waste strategies to achieve their milestone targets. San Francisco has a target of 100\% diversion of waste from landfill by 2020 and by 2018 the city diverts about $80 \%$ of its waste from landfills or more than 1.5 million tons every year [15]. Adelaide also has zero-waste strategies for moving towards a zero-waste city. In 2016-2017, 83\% of all waste generated in Adelaide was diverted from landfill. This equates to 4.40 million tonnes of material not going to waste [34]. Effective management strategies with realistic targets are thus imperative for moving towards zerowaste.

\section{Strategies for zero plastic waste}

A zero plastic waste framework has been adopted from the previous study done by Zaman [89]. Table 3 extends from the previous study on the strategic framework and action plans for moving towards zero plastic waste. An empirical traffic light analysis (e.g. green, yellow and red) was applied as a case study in Australia to understand the applicability of the framework. Four selected groups of stakeholders in (national and state governments, local government area- LGA, community and family and industry) have been analysed based on their relevance and importance (low- 1, medium- 2 and high- 3 ) of the action plans in Table 3.

The results of applying the framework showed that the local government scored the highest score of 58 out of 87 points followed by industry (53), community and individual (52) and national and state governments scored 50 in various zero plastics waste strategic action plans. In the Australian context, the local government is responsible for providing waste management services to the residence, thus the higher relevance and importance for local government is expected. Although both individual/community and industry are scored quite similar, it shows the shared responsibility of the individual/community as consumers and industry as producers regarding plastic waste management.

In relation to the industry roles in implementing the zero waste framework, industry scored the second highest (53 points). Industry and corporate companies have significant responsibilities in reducing the global emission footprint since only 100 giant companies are responsible for $71 \%$ (nearly 1 trillion tonnes) of global GHG emissions [35]. Despite the disruption of production and consumption due to COVID19, Coca-Cola was named as the company with the largest plastic footprint on earth with 2.9 million metric tonnes of plastic packaging produced annually, followed by Pepsico ( 2.3 millon metric tonnes) and Nestlé (1.7 million metric tonnes) [48]. The pressure has been mounting on these large polluters to increase their responsibility through greater 

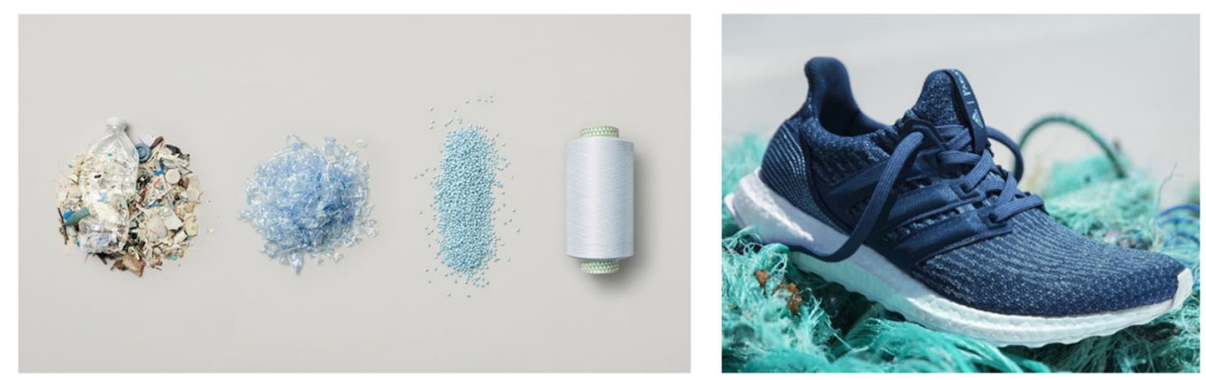

Fig. 9 Converting ocean plastic into yarn (Perley [59], with permission)

action [40]. Significantly fewer companies are responsible for plastics and these companies in particular need to play a significant role in reducing plastics pollution around the globe.

Several initiatives driven by business organisations have been implemented and are in-progress to tackle plastics waste, for example the Alliance to End Plastic Waste (AEPW) and the Sea the Future (StF) proposed by mining billionaire Andrew Forrest [22, 27]. The AEPW's goal is to invest US $\$ 1.5$ billion over the period 2020-2025, to help end plastic waste in the environment through industry participants (currently over $40 \mathrm{com}$ panies). The StF aims at raising US $\$ 300$ million from global plastics producing and consuming companies such as Coca-Cola Company, Walmart and Unilever as voluntary contributions to solve global problems though the circular economy solution.

\section{The long-term zero toxic agenda}

The above analysis has shown how important it is that plastic is managed as far as is possible under the zerowaste agenda, however this will not be enough. We believe that plastic as a toxic material needs to be phased out entirely as part of the long-term non-toxic environment or zero-toxic agenda. The Basel Convention Plastic Waste Amendments in 2019 put emphasis on the toxicity of plastics. Under the proposed amendments, countries will have to monitor the destination and time when plastics leave their borders. This should significantly reduce the unauthorised movement of plastics from developed countries to developing countries and result in less illegal dumping to the marine environment.

Several studies [14, 49] have laid emphasis on the cradle-to-cradle design and eco-effectiveness as alternative design agendas for moving beyond zero emission and eliminating toxicity. However, for synthetic plastics, the toxicity can be caused by breaking down of plastics into microplastics owing to material degradation in the environment and by that stage it is impossible to recycle. There seems to be no way of preventing plastic from breaking down into microparticles which are then an ecosystem and health hazard. As plastic is $99 \%$ derived from oil which also needs to be removed by 2050 as part of the Paris Agreement, we are therefore suggesting that oil-based plastics should be removed as part of the transition to the post-fossil fuel era.

The vision for a plastic free world may sound utopian given the fact that plastics have been used in almost all economic sectors and the plastics industry contributes significantly to the global economy - around USD 522.66 bn in 2017 [36]. The plastics industry uses around $4 \%$ of annual total use of oil and gas worldwide for the production of plastic products [10], making the industry highly dependent on fossil fuel, a finite natural resource that is currently being phased out through global processes to protect us from extreme climate change [39]. Although global oil production has increased more than 2.5 -fold over the last 50 years [64], the transition from fossil fuel-based energy to non-fossil fuel-based renewable energy options has begun. The transport industry has already been planning and transforming to enable the post-petroleum era $[43,52,53,74]$, but the removal of oil-based plastics has not been seen to be part of this agenda. There are many advantages in terms of global governance processes to include oil-based plastic removal as part of the global climate change agenda: for a start, there is a real link in terms of oil-based plastic being a $\mathrm{CO}_{2}$ contributor, but most importantly, because the conversations are already happening on a global scale, they can and should include plastic due to its toxicity. The phasing out of chlorinated hydrocarbon pesticides has been a continuing process of diminishing the need for pesticides and replacing them with more healthy alternatives. The same can be done with plastics by phasing out oil-based plastics and using biological materials that are entirely biodegradable and recyclable, such as the use of cellulose or cellophane, called bioplastics.

\section{Conclusion and recommendations}

The conclusions are set out under the goals as set out in the beginning of the paper.

1. Analyse the key challenges of plastics waste management based on a review of grey and 
Table 3 The strategic framework and action plans for moving towards zero plastic waste (adapted from Zaman, 2017)

\begin{tabular}{|c|c|c|c|c|c|c|c|}
\hline Phases & Strategic elements & Action plan & Example & $\begin{array}{l}\text { National/ } \\
\text { State }\end{array}$ & LGA & $\begin{array}{l}\text { Community/ } \\
\text { Individual }\end{array}$ & $\begin{array}{l}\text { Indust } \\
\text { ry }\end{array}$ \\
\hline \multirow{15}{*}{$\begin{array}{l}\text { Waste } \\
\text { prevention and } \\
\text { reduction }\end{array}$} & \multirow{2}{*}{$\begin{array}{l}\text { Effective public } \\
\text { awareness and } \\
\text { education on plastics } \\
\text { waste }\end{array}$} & $\begin{array}{l}\text { Inclusion of waste } \\
\text { education program at the } \\
\text { school curriculum }\end{array}$ & Primary school & 3 & 2 & 2 & 0 \\
\hline & & $\begin{array}{l}\text { Organize awareness } \\
\text { promotional program on } \\
\text { plastics waste avoidance } \\
\text { and reduction }\end{array}$ & Plastics hackathon & 3 & 3 & 3 & 3 \\
\hline & \multirow{2}{*}{$\begin{array}{l}\text { Zero plastic waste } \\
\text { program }\end{array}$} & $\begin{array}{l}\text { Hands-on training and } \\
\text { knowledge sharing program }\end{array}$ & Crafts and design & 1 & 2 & 2 & 2 \\
\hline & & $\begin{array}{l}\text { Sustainable packaging and } \\
\text { consumption practices }\end{array}$ & $\begin{array}{l}\text { Avoid unnecessary } \\
\text { packaging }\end{array}$ & 3 & 2 & 3 & 3 \\
\hline & \multirow{2}{*}{$\begin{array}{l}\text { Sustainable and } \\
\text { responsible living }\end{array}$} & $\begin{array}{l}\text { Citizen initiatives through } \\
\text { responsible shopping and } \\
\text { consumption behavior }\end{array}$ & Buy loose items & 0 & 0 & 3 & 2 \\
\hline & & $\begin{array}{l}\text { Promote local farmers } \\
\text { market }\end{array}$ & Popup shops & 1 & 2 & 3 & 2 \\
\hline & \multirow{2}{*}{$\begin{array}{l}\text { Shared-ownership of } \\
\text { product and service }\end{array}$} & Collaborative consumption & Borrow/resell & 1 & 1) & 2 & 1 \\
\hline & & $\begin{array}{l}\text { Owning services rather than } \\
\text { owning products }\end{array}$ & $\begin{array}{l}\text { Renting instead of } \\
\text { owning }\end{array}$ & 3 & 3 & 3 & 3 \\
\hline & \multirow{2}{*}{$\begin{array}{l}\text { Zero plastic waste } \\
\text { products }\end{array}$} & The designing for reuse & $\begin{array}{l}\text { Cradle-to-cradle } \\
\text { product }\end{array}$ & 2 & 0 & 0 & 3 \\
\hline & & $\begin{array}{l}\text { Alternative use of plastics } \\
\text { waste }\end{array}$ & Storage container & 0 & 1 & 2 & 0 \\
\hline & \multirow{2}{*}{$\begin{array}{l}\text { Extended producer } \\
\text { responsibility }\end{array}$} & $\begin{array}{l}\text { Mandatory take-back } \\
\text { scheme for producers }\end{array}$ & Swap & 2 & 1 & 1 & 3 \\
\hline & & Container deposit scheme & Retum & 3 & 3 & 3 & 3 \\
\hline & \multirow{3}{*}{$\begin{array}{l}\text { Extend the life of } \\
\text { post-consumer items }\end{array}$} & Resell and repair & Gumtree/ eBay & 0 & 0 & 2 & 1 \\
\hline & & $\begin{array}{l}\text { Men's shed or community } \\
\text { resource center }\end{array}$ & Men's shed & 0 & 3 & 2 & 0 \\
\hline & & $\begin{array}{l}\text { Promote competitive } \\
\text { recycling market }\end{array}$ & Green procurement & 3 & 3 & 2 & 3 \\
\hline \multirow{12}{*}{$\begin{array}{l}\text { Waste } \\
\text { management } \\
\text { and treatment }\end{array}$} & \multirow{4}{*}{$\begin{array}{l}\text { Appropriate waste } \\
\text { infrastructure } \\
\text { (centralized and } \\
\text { decentralized) }\end{array}$} & Mandatory 3 bin & $\begin{array}{l}\text { Food organic } \\
\text { garden organic } \\
\text { (FOGO) }\end{array}$ & 0 & 3 & 0 & 0 \\
\hline & & Plastic sorting infrastructure & $\begin{array}{l}\text { Optical/ density } \\
\text { sensor }\end{array}$ & 2 & 2 & 0 & 2 \\
\hline & & Takeback points & Reverse vending & 0 & 3 & 2 & 3 \\
\hline & & $\begin{array}{l}\text { Community, precinct-based } \\
\text { drop-off points }\end{array}$ & Drop-off point & 0 & 3 & 2 & 0 \\
\hline & \multirow{2}{*}{$\begin{array}{l}\text { Empower social } \\
\text { technologies }\end{array}$} & $\begin{array}{l}\text { Social business for plastics } \\
\text { recycling }\end{array}$ & $\begin{array}{l}\text { Small Medium } \\
\text { Enterprises (SMEs) }\end{array}$ & 1 & 1 & 1 & 2 \\
\hline & & $\begin{array}{l}\text { Re-use, repair and recycle } \\
\text { through community } \\
\text { participation }\end{array}$ & $\begin{array}{l}\text { Community } \\
\text { business }\end{array}$ & 0 & 1 & 2 & 0 \\
\hline & \multirow{3}{*}{ Regulatory policies } & Improved policy & $100 \%$ packaging & 3 & 0 & 0 & 3 \\
\hline & & Polluters pay principles & $\begin{array}{l}\text { Pay as you throw } \\
\text { (PAYT) scheme }\end{array}$ & 1 & 3 & 2 & 0 \\
\hline & & $\begin{array}{l}\text { Incentives for green } \\
\text { initiatives }\end{array}$ & Green procurement & 3 & 3 & 1 & 2 \\
\hline & $\begin{array}{l}\text { Restrictions on } \\
\text { Waste to Energy } \\
\text { technology }\end{array}$ & Interim use of WtE & Temporary use & 3 & 2 & 0 & 0 \\
\hline & $\begin{array}{l}\text { Landfill ban for } \\
\text { plastics waste }\end{array}$ & $\begin{array}{l}\text { A } 100 \% \text { plastics waste } \\
\text { diversion from landfill }\end{array}$ & $100 \%$ diversion & 3 & 3 & 3 & 3 \\
\hline & Economic incentive & Refund, landfill levy, etc. & $10 \mathrm{c} /$ levy & 3 & 3 & 3 & 3 \\
\hline \multirow{2}{*}{$\begin{array}{l}\text { Monitoring } \\
\text { and } \\
\text { assessment }\end{array}$} & $\begin{array}{l}\text { Standardized data } \\
\text { collection systems }\end{array}$ & $\begin{array}{l}\text { Mandatory online data } \\
\text { collection system }\end{array}$ & Online platform & 3 & 3 & 2 & 3 \\
\hline & $\begin{array}{l}\text { Research on zero } \\
\text { plastic waste }\end{array}$ & $\begin{array}{l}\text { zero plastic waste research } \\
\text { collaboration }\end{array}$ & $\begin{array}{l}\text { National/internatio } \\
\text { nal collaboration }\end{array}$ & 3 & 2 & 1 & 3 \\
\hline \multicolumn{4}{|c|}{ Total scores (out of a maximum of 87 points) } & 50 & 58 & 52 & 53 \\
\hline
\end{tabular}


scholarly literature. Plastics are now one of the major constituents of the human waste stream and they are also one of the rapidly growing sources of toxic waste in the marine environment (as discussed in Section 4.2).

2. Examine the concept of zero-waste and how it would address the challenges through the analysis of current zero-waste practices. Almost all consumer products that we buy today use some form of plastics. Although plastics were once considered as 'magical' materials, the planet is now drowning in plastics and plastic-related waste. The very characteristic of plastic material as low-degradability gives plastics their unique characteristics, but it has now been considered as one of the serious concerns for individuals, scientists, communities, industries and governments, to manage it sustainably (presented in Section 4).

3. Examine the reasons for considering plastic wastes as toxic and how to move towards a non-toxic environment. Global plastics recycling performance (only 9\%) indicates that we have failed in managing plastics waste so far. This means that the vast majority of plastic wastes are entering the environment and breaking down into toxic micro and nano particles. This paper therefore suggests a two phase process based on a short-term adoption of the zero-waste agenda for plastics as they move through the household, business and city economies (as presented in Section 5) and at the same time the beginning of a long term adoption of the toxicwaste agenda that aims at phasing out plastics in the post fossil-fuel era (as presented in Section 5).

4. Provide a set of strategic recommendations for implementing both short-term zero plastic waste and long-term zero-toxic waste agendas. Based on the above analysis, the authors propose the following short-term (zero plastics waste) and long-term (zero toxic waste) agenda targets presented in Table 4 based on current benchmark performances and practices as part of policy recommendations.

Realising the complexity of the plastics' challenges, the material circularity of plastics through recycling needs to be increased from 9 to $80 \%$ in the short term and during the same time both incineration and landfills can be used as interim solutions rather than the ultimate solutions. Through innovative design and technological solutions including social technologies, the recycling rate can be achieved nearly $100 \%$. However, the focus on synthetic plastics material circularity is not enough. The zero-toxic agenda needs to consider not only to ensure material circularity, but also to phasing out of plastic toxicity in the future. Currently only $1 \%$ plastics are sourced from bioplastics and in the short-term the rates need to be increased to $10 \%$ and eventually to $100 \%$ in the long term.

In the long-term, nation states worldwide will need the UN to link the post-fossil fuel agenda of the IPCC and the Paris Agreement to include the Basel Convention to enable a joint banning or phasing out of oilbased plastic as part of their co-ordinated agendas. The first plastics to be banned should be those that are the most toxic which will involve science-based processes for plastic removal to be established globally like the IPCC process which collates the science base for the world to use. Is it possible to reach the point when innovative and bio-based natural plastics will replace the need for synthetic plastics or do we need to make use of plastics that have already been discarded? Urban mining (mining of secondary raw materials from urban settings e.g. landfills, electronic waste) could be an alternative option in the post-fossil fuel era to source the secondary materials in order to produce plastics. However, this would continue the use of a material that has toxic breakdown properties. These innovations in the zerowaste agenda are not addressing the toxic-waste agenda.

The toxic-waste agenda demands that oil-based plastics are replaced by bioplastics. We have already seen the growing demand for biodegradable natural plastics [28]. This demonstrates that high quality durable products can be manufactured from bioplastics and they can have significantly less impact on the environment [28]. Figure 10 shows various products made out of bioplastics [61].

As an alternative to oil-based plastic, it is important to develop a strategy in parallel to other global agendas which can begin the phasing out of oil-based plastic and replacing with bioplastics. This can be done by groups associating this phase-out with the global climate agenda

Table 4 Zero-waste and zero toxic plastics agenda targets for sustainable future

\begin{tabular}{llll}
\hline Indicators & Current performance & Short-term (zero plastic waste) & Long-term (zero toxic waste) \\
\hline Plastics recycling & $9 \%$ & $80 \%$ & $100 \%$ \\
Interim plastics incineration & $12 \%$ & $1-2 \%$ & $0 \%$ \\
Interim plastics landfill & $79 \%$ & $20 \%$ & $0 \%$ \\
Proportion of fossil fuels based synthetic plastics & $99 \%$ & $90 \%$ & $0 \%$ \\
Bioplastics & $1 \%$ & $10 \%$ & $100 \%$ \\
\hline
\end{tabular}



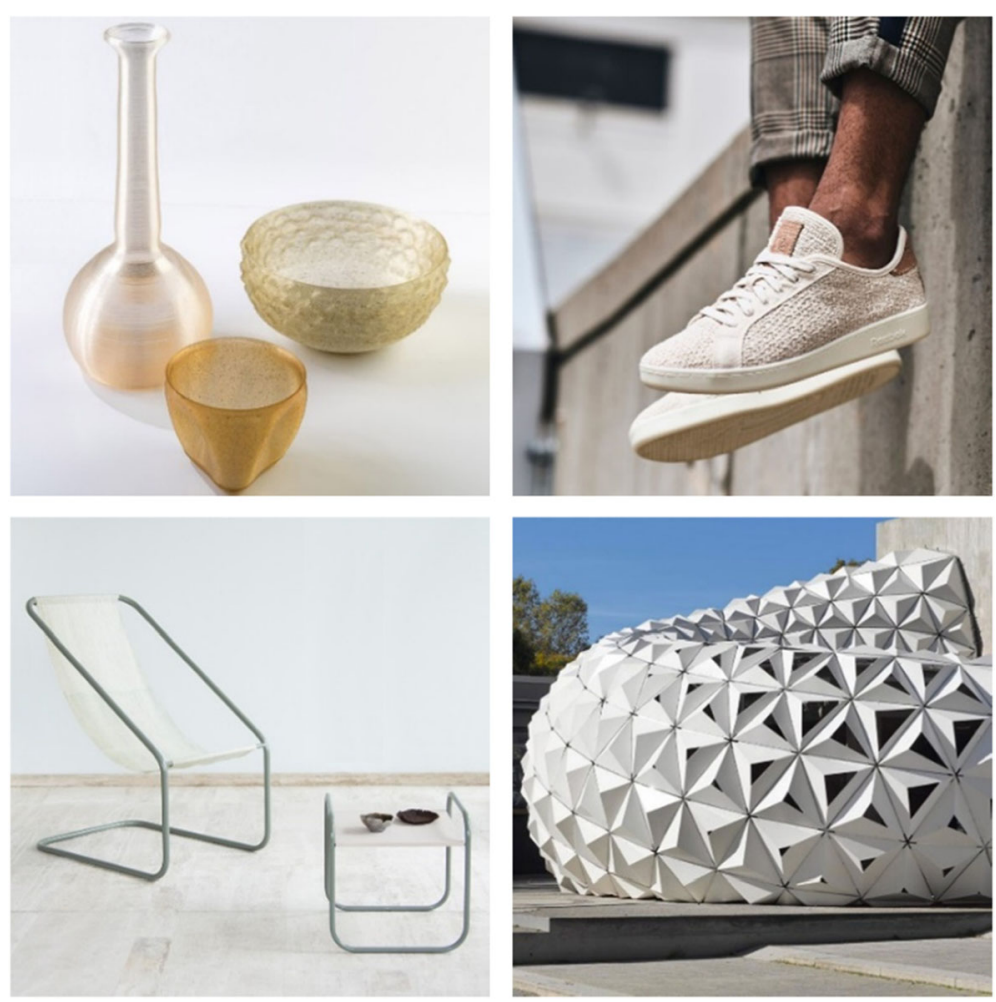

Fig. 10 Products made-out of bio-plastics [61]. Clockwise from top left: (i)3D-printed biopolymer plastic by Erik Klarenbeek and Maartje Dros; ii) bioplastic sole made from corn by Reebok; iii) ArboSkin pavilion by ITKE; iv) Sea Me seaweed furniture and bioplastic bowls by Studio Nienke Hoogvliet)

run through the IPCC and UNFCCC. The parties involved in the Basel Agreement need to meet with the parties involved in the Paris Agreement. Such sciencebased assessment can work with industry and national governments to create and coordinate a long-term agenda committed to phasing out fossil fuels. A synchronised removal of fossil fuels from the global economy needs to include plastics from oil.

In this article we have explored the zero-waste and zero-toxic concepts in the context of plastic waste issues. Undoubtedly, the zero plastic waste agenda is a visionary and challenging target, considering that plastic is used in a majority of the consumer products and the growth of plastics waste seems to increase due to their huge demand. The implementation of zero plastic waste is needed to ensure the material circularity within the urban system. In addition to the zero plastic agenda, this article also emphasizes that the zero-toxic agenda is even more important for plastic waste as they significantly pollute our environment. Zero waste primarily deals with material circularity and not necessarily the toxicity of the materials and products. Therefore, the toxic waste agenda is vital while developing strategies around plastic waste.
We conclude that a Sustainable Earth will need to think beyond recycling of plastics and thus the policy agenda should consider both zero plastic waste as a short-term agenda and zero-toxic plastics as a long-term agenda to combat the challenges of plastics waste around the globe.

\section{Abbreviations}

ACC: American Chemistry Council; AEPW: Alliance to end plastic waste; GPGP: Great pacific garbage patch; FOGO: Food organic garden organic; HDPE: High-density polyethylene; IPCC: Intergovernmental Panel on Climate Change; PE: Polyethylene; PET: polyethylene terephthalate; PAYT: Pay as you throw; PP: Polypropylene; PS: Polystyrene; PVC: Polyvinyl chloride; SMEs: Small medium enterprises; StF: Sea the future; UN: United Nations; UNFCCC: United Nations Framework Convention on Climate Change; WtE: Waste-to-energy; ZPW: Zero-plastic waste; ZW: Zero-waste

\section{Acknowledgements}

The authors acknowledge the support provided by Curtin University Sustainability Policy Institute. The authors declare no conflict of interest of the study and there was no funding to conduct the research.

\section{Authors' contributions}

The conceptualisation, data curation, formation and data analysis of zerowaste agenda by A.Z. and the conceptualisation and discussion on zero-toxic agenda by P.N. The original drafting by A.Z. and proof reading by P.N. The author(s) read and approved the final manuscript.

\section{Funding}

Not applicable. 


\section{Availability of data and materials}

Not applicable.

\section{Ethics approval and consent to participate}

Not applicable.

\section{Consent for publication}

The authors provide consent for publishing the article online.

\section{Competing interests}

The authors declare no competing interests.

Received: 3 March 2020 Accepted: 1 February 2021

Published online: 18 February 2021

\section{References}

1. $\quad$ MWW. We Chat To Australia's Zero Waste Family. 2016. from www.1 millionwomen.com.au/blog/we-chat-australias-zero-waste-family/.

2. ACC. Plastics. 2019. Retrieved 20 October 2019, from https://plastics.america nchemistry.com/How-Plastics-Are-Made/. Accessed 20 Oct 2019.

3. Achterberg, E., J Hinfelaar and N. Bocken. Master circular business with the value hill. 2016. White paper. Financing Circular Business. http://www.circleeconomy.com/financing-circular-business. Accessed 20 Nov 2019.

4. Adidas-Group. Messi's Boots Today, Recycled Into Yours Tomorrow. 2015 Retrieved 15 February 2019, from https://www.adidas-group.com/media/ filer_public/51/cd/51cd8d06-a718-4445-a4e7-5fa99d601424/sport_infinity_ press_release_en.pdf

5. Albalawi Y, Sixsmith J. Agenda setting for health promotion: exploring an adapted model for the social media era. JMIR Public Health Surveill. 2015; 1(2):e21.

6. Andrady AL. Plastics and the Environment. Toronto: Wiley; 2003.

7. APCO. Market Impact Assessment Report Chinese Import Restrictions for Packaging in Australia. 2018. Retrieved 2 November 2018, from https:// www.packagingcovenant.org.au/documents/item/1224.

8. Basel Action Network. Plastic Waste Partnership. 2019. from http://www.ba sel.int/Implementation/Plasticwastes/PlasticWastePartnership/tabid/8096/ Default.aspx

9. BBC. Seven charts that explain the plastic pollution problem. Sci Environ. 2017; Retrieved 18 November 2018, from https://www.bbc.com/news/ science-environment-42264788. Accessed 5 Oct 2019.

10. Beckman, E.. The world of plastics: in numbers. 2018. from https:// theconversation.com/the-world-of-plastics-in-numbers-100291.

11. Benzaken, H. 5 companies that embrace the concept of a circular economy. 2018. Retrieved 11 February 2020, 2020, from https://www.goodnet.org/a rticles/5-companies-that-embrace-concept-circular-economy.

12. Blue Environment. Data on exports of Australian wastes. 2019. from https:// www.environment.gov.au/system/files/resources/3e7b446f-0c76-492c-93 e6-4ad15b473a30/files/data-exports-australian-wastes-issue-3.pdf.

13. Eco Boost. Here to buy bulk in London: zero waste grocery shopping. 2017. from http://eco-boost.co/where-to-buy-bulk-in-london/

14. Braungart $M$, McDonough W, Bollinger A. Cradle-to-cradle design: creating healthy emissions - a strategy for eco-effective product and system design. J Clean Prod. 2007;15(13-14):1337-48

15. Brigham, K. How San Francisco sends less trash to the landfill than any other major U.S. city. 2018. Retrieved 14 July 2018, from https://www.cnbc. com/2018/07/13/how-san-francisco-became-a-global-leader-in-waste-mana gement.html

16. Browne MA, Crump P, Niven SJ, Teuten E, Tonkin A, Galloway T, Thompson R. Accumulation of microplastic on shorelines woldwide: sources and sinks. Environ Sci Technol. 2011:45(21):9175-9.

17. Brun NR, van Hage P, Hunting ER, Haramis A-PG, Vink SC, Vijver MG, Schaaf MJ, Tudorache C. Polystyrene nanoplastics disrupt glucose metabolism and cortisol levels with a possible link to behavioural changes in larval zebrafish. Commun Biol. 2019;2(1):1-9.

18. Carson R. Silent spring. Boston: Massachusetts, Houghton Mifflin Company; 1962.

19. Clifford, J. New recycling technology to keep 90 per cent of household waste out of landfill. 2019. Retrieved 23 January 2019, from https://www.a bc.net.au/news/2019-01-23/new-recycle-technology-to-keep-90pc-of-wasteout-of-landfill/10736142
20. Cosgrove, B. 'Throwaway Living': when tossing out everything was all the rage. 2014. Retrieved 5 March 2019, from https://time.com/3879873/throwa way-living-when-tossing-it-all-was-all-the-rage/

21. Costa JP d. Nanoplastics in the Environment. Plastics and the Environment. R. M. Harrison and R. E. Hester. London: Royal Society of Chemistry; 2018.

22. Cox, L. Andrew Forrest launches US\$300m war on plastic to tackle ocean pollution. 2019. Retrieved 25 September 2019, from https://www.theguardia n.com/australia-news/2019/sep/25/andrew-forrest-launches-us300m-war-onplastic-to-tackle-ocean-pollution

23. Crawford CB, Quinn B. Microplastic pollutants. Amsterdam: Netherlands, Elsevier Science; 2016

24. Dormer A, Finn DP, Ward P, Cullen J. Carbon footprint analysis in plastics manufacturing. J Clean Prod. 2013;51:133-41.

25. Earth Day Network. Plastic pollution primer and action toolkit: end plastic pollution. Earth Day. 2018;2018 Retrieved 5 June 2019, from http://160g7a3 snajg2i1r662yjd5r-wpengine.netdna-ssl.com/wp-content/uploads/PlasticPollution-Primer-and-Action-Toolkit.pdf. Accessed 9 Sept 2019.

26. Ellen MacArthur Foundation. What is a circular economy? 2019. Retrieved 25 June 2019, from https://www.ellenmacarthurfoundation.org/circulareconomy/concept.

27. End of Plastic Waste. The Alliance to End Plastic Waste. 2019. from https:// endplasticwaste.org/

28. European Bioplastics. Global production capacities of bioplastics 2018-2023. 2018. from https://www.european-bioplastics.org/wp-content/uploads/2016/ 02/Report_Bioplastics-Market-Data_2018.pdf

29. European Commission. Study for the strategy for a non-toxic environment of the 7th Environment action Programme, final report. Brussels: European Commission; 2017. from https://ec.europa.eu/environment/chemicals/nontoxic/pdf/NTE\%20main\%20report\%20final.pdf

30. Freinkel S. A brief history of plastic's conquest of the world. Sci Am. 2011; from https://www.scientificamerican.com/article/a-brief-history-of-plasticworld-conquest/. Accessed 2 Nov 2019.

31. Garfield, L. The simple way this Japanese town has become nearly zerowaste. 2018. 31 January 201828 December 2018, from https://www. independent.co.uk/environment/recycling-zero-waste-town-garbage-pla stics-kamikatsu-japan-a8187301.html. Accessed 2 Nov 2019.

32. Geyer R, Jambeck JR, Law KL. Production, use, and fate of all plastics ever made. Sci Adv. 2017:3(7):e1700782.

33. Glavič P, Lukman R. Review of sustainability terms and their definitions. J Clean Prod. 2007:15(18):1875-85.

34. Green Industries SA. South Australia's recycling activity in 2016-17. 2018. from https://www.greenindustries.sa.gov.au/SArecycling

35. Griffin, P. The Carbon Majors Database CDP Carbon Majors Report 2017: 100 fossil fuel producers and nearly 1 trillion tonnes of greenhouse gas emissions. 2017. From https://b8f65cb373b1b7b15feb-c70d8ead6ced550b4 d987d7c03fcdd1d.ssl.cf3.rackcdn.com/cms/reports/documents/000/002/327/ original/Carbon-Majors-Report-2017.pdf.

36. GVR. Plastics Market Size, Share, Industry Analysis Report, 2019-2025. 2019. from https://www.grandviewresearch.com/industry-analysis/global-plasticsmarket.

37. Habbu VG. PLASTIC WASTE: best technologies \& global practices. India: ASSOCHAM National Conference on "WASTE to WEALTH", ASSOCHAM National Conference; 2017

38. Harvey, F. and J. Watts. Microplastics found in human stools for the first time. 2018. Retrieved 2 November 2018, from https:/www.theguardian.com/ environment/2018/oct/22/microplastics-found-in-human-stools-for-the-first-time

39. IPCC. Climate Change 2014: Impacts, Adaptation and Vulnerability. 2014 Retrieved 2 April 2015, from http://ipcc-wg2.gov/Ar5/images/uploads/IPCC WG2AR5_SPM_Approved.pdf.

40. IPCC. Global Warming of $1.5^{\circ} \mathrm{C}$. An IPCC Special Report on the impacts of global warming of $1.5^{\circ} \mathrm{C}$ above pre-industrial levels and related global greenhouse gas emission pathways, in the context of strengthening the global response to the threat of climate change, sustainable development, and efforts to eradicate poverty. V. Masson-Delmotte, P. Zhai, H.-O. Pörtner, D. Roberts, J. Skea, P.R. Shukla, A. Pirani, W. Moufouma-Okia, C. Péan, R. Pidcock, S. Connors, J.B.R. Matthews, Y. Chen, X. Zhou, M.I. Gomis, E. Lonnoy, T. Maycock, M. Tignor, and T. Waterfield. Geneva: IPCC; 2018. p. 1.

41. Johnson B. Zero waste home: the ultimate guide to simplify your life by reducing your waste. New York: Simon and Schuster Inc; 2013.

42. Katz, C. Piling up: how China's ban on importing waste has stalled global recycling. 2019. Yale Environment retrieved march, 360, from https://e360.ya 
le.edu/features/piling-up-how-chinas-ban-on-importing-waste-has-stalledglobal-recycling.

43. Kenworthy J. Urban planning and transport paradigm shifts for cities of the post-petroleum age. J Urban Technol. 2007;14(2):47-70.

44. Kostigen TM, Magazine FD. The world's largest dump: the great pacific garbage patch. Discov Magazine. 2008:10.

45. LeBlanc R. How long does it take garbage to decompose. Balance. 2017; https://www.discovermagazine.com/environment/the-worlds-largest-dumpthe-great-pacific-garbage-patch.

46. Lebreton L, Slat B, Ferrari F, Sainte-Rose B, Aitken J, Marthouse R, Hajbane S, Cunsolo S, Schwarz A, Levivier A. Evidence that the great Pacific garbage patch is rapidly accumulating plastic. Sci Rep. 2018;8(1):4666.

47. Lebreton LC, Van der Zwet J, Damsteeg JW, Slat B, Andrady A, Reisser J. River plastic emissions to the world's oceans. Nat Commun. 2017;8:15611.

48. McCarthy, Niall. PLASTIC POLLUTION: The World's Worst Offenders For Plastic Pollution, Statista. 2020. Available on https://www.statista.com/cha rt/22959/metric-tonnes-of-plastic-packaging-produced-annually/?utm _ source=Statista+Global\&utm_campaign=1fabb161d8-All_InfographTicker_da ily_COM_AM_KW39_2020_Tu\&utm_medium=email\&utm_term=0_afecd21 9f5-1fabb161d8-299542021

49. McDonough W. Cradle to cradle: remaking the way we make things. New York: North Point Press; 2002

50. Milman, O. Great Pacific garbage patch' sprawling with far more debris than thought. 2018. Retrieved 23 March 2018, from https://www.theguardian. com/environment/2018/mar/22/great-pacific-garbage-patch-sprawling-withfar-more-debris-than-thought

51. Mlynek, A. How we became a zero waste family. 2018. from www.todayspa rent.com/family/activities/how-we-became-a-zero-waste-family/

52. Newman P. Covid, cities and climate: historical precedents and potential transitions for the new econnmy. Urban Sci. 2020;4(3):32 https://doi.org/1 $0.3390 /$ urbansci4030032.

53. Newman P, Beatley T, Boyer H. Resilient cities: Overcoming fossil fuel dependence. Washington: Island Press; 2017.

54. Newman P, Matan A. Green urbanism in Asia: the emerging green tigers. Singapore: World Sci; 2013.

55. Nicholson JL, Leighton GR. Plastics come of age. Harper's Magazine. 1942; 1942(0):306.

56. Ocean Cleanup. The great Pacific garbage patch. 2019. from https://theocea ncleanup.com/great-pacific-garbage-patch/

57. Parker, L. Planet or plastics: we made plastic, we depend on it, now we're drowning in it. 2018. Retrieved 12 July 2019, from https://www.nationalgeogra phic.com/magazine/2018/06/plastic-planet-waste-pollution-trash-crisis/

58. Pauly JL, Stegmeier SJ, Allaart HA, Cheney RT, Zhang PJ, Mayer AG, Streck RJ. Inhaled cellulosic and plastic fibers found in human lung tissue. Cancer Epidemiol Prev Biomark. 1998;7(5):419-28.

59. Perley. The Parley Air Strategy. 2018. Retrieved 24 January 2019, from https:/www.parley.tv/oceanplastic/\#the-mission

60. PlasticsEurope. Plastics - the facts 2016: an analysis of European plastics production, Demand and Waste Data. Brussels: Plastics Europe; 2016.

61. Pownall, A. 10 bioplastic projects made from algae, corn starch and other natural materials. 2018. Retrieved 9 October 2018, from https://www.dezeen. com/2018/10/09/bioplastic-projects-algae-corn-starch-beetle-shells/

62. Quackenbush C. Researchers have found microplastics in human waste for the first time. Scie Environ. 2018; Retrieved 23 November 2018, from https:// time.com/5431668/microplastics-human-waste-study/. Accessed 3 Oct 2019.

63. Raubenheimer K, Mcllgorm A. Can the Basel and Stockholm conventions provide a global framework to reduce the impact of marine plastic litter? Mar Policy. 2018;96:285-90.

64. Ritchie, H. and M. Roser. Fossil fuels. 2019. from https://ourworldindata.org/ fossil-fuels.

65. Ritchie, M. The state of waste in Australia - a 2019 review. 2019. Retrieved 14 August 2019, from https://www.insidewaste.com.au/index.php/2019/ 08/14/a-review-of-the-state-of-waste-in-australia-in-2019/

66. Rochman CM, Browne MA, Halpern BS, Hentschel BT, Hoh E, Karapanagioti HK, Rios-Mendoza LM, Takada H, Teh S, Thompson RC. Classify plastic waste as hazardous. Nature. 2013:494(7436):169-71.

67. Rogers E, Dearing J. Agenda-setting research: where has it been? Where is it going? In: Anderson J, editor. Communication yearbook. 11th ed. Newbury Park: Sage; 1988. p. 555-94.

68. Royer S-J, Ferron S, Wilson ST, Karl DM. Production of methane and ethylene from plastic in the environment. Plos One. 2018;13(8):e0200574
69. Schlossberg, T. The immense, eternal footprint humanity leaves on earth: plastics. 2017. 19 June 20172 July 2019, from https:/www.nytimes.com/201 7/07/19/climate/plastic-pollution-study-science-advances.html?mtrref=www. google.com\&gwh=89525DBCE85046E32B1 15A06582007E6\&gwt=pay.

70. Seadon, J. How recycling is actually sorted, and why Australia is quite bad at it. 2019. Retrieved 14 August 2019, from http://theconversation.com/howrecycling-is-actually-sorted-and-why-australia-is-quite-bad-at-it-121120.

71. Shent H, Pugh R, Forssberg E. A review of plastics waste recycling and the flotation of plastics. Resour Conserv Recycl. 1999;25(2):85-109.

72. Sivaram N, Gopal P, Barik D. Toxic waste from textile industries, Energy from Toxic Org Waste Heat Power Gener; 2018. p. 43-54.

73. Spring, A. and C. Earl. Plastic packaging pictures - send us your best worst examples. 2018. Retrieved 8 July 2018, from https://www.theguardian.com/ environment/gallery/2018/jul/08/waste-crisis-spot-the-excessive-plastic-pa ckaging-in-pictures.

74. Stone J, Mees P. Planning public transport networks in the post-petroleum era. Australian Plann. 2010;47(4):263-71.

75. Stumm W, Morgan JJ. Aquatic chemistry; an introduction emphasizing chemical equilibria in natural waters; 1970 .

76. Sturmer, J. Kamikatsu: The Japanese town working towards a zero-waste goal by 2020. 2018. Retrieved 20 May 2018, from https://www.abc.net.au/ news/2018-05-20/kamikatsu-the-japanese-town-with-45-different-recyclingbins $/ 9776560$

77. Thiel M, Luna-Jorquera G, Álvarez-Varas R, Gallardo C, Hinojosa IA, Luna N, Miranda-Urbina D, Morales N, Ory N, Pacheco AS. Impacts of marine plastic pollution from continental coasts to subtropical gyres-fish, seabirds, and other vertebrates in the SE Pacific. Front. Mar Sci. 2018;5(238) https://doi. org/10.3389/fmars.2018.00238.

78. Time for Change. Plastic bags and plastic bottles - $\mathrm{CO} 2$ emissions during their lifetime. 2009. From http://timeforchange.org/plastic-bags-and-plasticbottles-co2-emissions-during-their-lifetime/.

79. UN-HABITAT. Solid waste management in the world's cities: water and sanitation in the world's cities. London: Earthscan; 2010.

80. VAMSC. Microplastic in Aquatic Food Webs. 2015. Retrieved 24 June 2019 , from https://www.reef2rainforest.com/2015/07/28/microplastic-in-marinefood-webs/.

81. Van Houtan KS, Francke DL, Alessi S, Jones TT, Martin SL, Kurpita L, King CS, Baird RW. The developmental biogeography of hawksbill sea turtles in the North Pacific. Ecol Evol. 2016;6(8):2378-89.

82. Verma R, Vinoda K, Papireddy M, Gowda A. Toxic pollutants from plastic waste-a review. Procedia Environ Sci. 2016;35:701-8.

83. WECF. Dangerous health effects of home burning of plastic and wastes. 2004. Women in Europe for a Common Future Fact Sheet from http://www. wecf.eu/cms/download/2004-2005/homeburning_plastics.pdf

84. Yarsley VE, Couzens EG. Plastics. Allen Lane. London: Penguin Books; 1941.

85. Young LC, Vanderlip C, Duffy DC, Afanasyev V, Shaffer SA. Bringing home the trash: do colony-based differences in foraging distribution lead to increased plastic ingestion in Laysan albatrosses? Plos One. 2009;4(10):e7623.

86. Zahariadis N. Handbook of public policy agenda setting. Cheltenham: Edward Elgar Publishing; 2016.

87. Zaman AU. A comprehensive review of the development of zero waste management: lessons learned and guidelines. J Clean Prod. 2015;91:12-25.

88. Zaman AU. A comprehensive study of the environmental and economic benefits of resource recovery from global waste management systems. J Clean Prod. 2016;124:41-50.

89. Zaman AU. A strategic framework for working toward zero waste societies based on perceptions surveys. Recycling. 2017;2(1):1.

90. Zaman, A. U. The new $100 \%$ recyclable packaging target is no use if our waste isn't actually recycled. 2018. Retrieved 27 June 2019, from https:// theconversation.com/the-new-100-recyclable-packaging-target-is-no-use-ifour-waste-isnt-actually-recycled-95857

91. Zaman AU, Ahsan T. Zero-waste: reconsidering waste Management for the Future. New York: Routledge; 2019.

92. Zheng J, Suh S. Strategies to reduce the global carbon footprint of plastics. Nat Clim Chang. 2019:9(5):374.

93. Zimmerman JB, Anastas PT, Erythropel HC, Leitner W. Designing for a green chemistry future. Science. 2020;367(476):397-400.

\section{Publisher's Note}

Springer Nature remains neutral with regard to jurisdictional claims in published maps and institutional affiliations. 